\title{
Antibodies against nodo-paranodal proteins are not present in genetic neuropathies
}

Lorena Martín-Aguilar, MD, Elba Pascual-Goñi, MD, Cinta Lleixà, MD, Marina Frasquet, MD, Herminia Argente, MD, Angel Cano-Abascal, MD, Jordi Diaz-Manera, MD, PhD, Elena Cortés-Vicente, MD, PhD, Ana Lara Pelayo-Negro, MD, PhD, Teresa Sevilla, MD, PhD, Ricard Rojas-García, PhD, and Luis Querol, MD, PhD Neurology ${ }^{\circledR}$ 2020;95:e427-e433. doi:10.1212/WNL.0000000000009189

\begin{abstract}
\section{Objective}

To study the presence of nodal and paranodal immunoglobulin $M$ ( $\operatorname{IgM})$ and immunoglobulin $\mathrm{G}(\mathrm{IgG})$ antibodies in patients with genetic neuropathies.
\end{abstract}

\section{Methods}

A total of 108 patients with genetic neuropathies from 3 different centers were included. The presence of IgG and IgM antibodies against neurofascin-155 (NF155), nodal neurofascin (NF186 and NF140), and contactin-1 (CNTN1) were investigated with a cell-based assay (CBA) using immunocytochemistry in transfected HEK293 cells. Sera with positive or uncertain results were further tested by ELISA and immunohistochemistry in pig teased-nerve fibers.

\section{Results}

Six patients with Charcot-Marie-Tooth disease (CMT) had an uncertain staining pattern for IgM against nodal neurofascin that was not confirmed by ELISA. Two patients with CMT had an uncertain staining pattern for IgG against nodal neurofascin that was not confirmed by ELISA or immunohistochemistry. One patient with CMT with a confirmed GJB1 mutation tested positive for IgG against NF155 by CBA and ELISA (1/900), but was not confirmed by immunohistochemistry and was ultimately classified as negative.

\section{Conclusions}

Antibodies against nodal or paranodal antigens were not detected in our cohort of patients with CMT, as previously reported. Some patients may falsely test positive for any of the techniques; confirmatory techniques should be incorporated into the routine testing.

\author{
Correspondence \\ Dr. Querol \\ Iquerol@santpau.cat
}




\section{Glossary}

CBA = cell-based assay; $\mathbf{C I D P}=$ chronic inflammatory demyelinating polyradiculoneuropathy; $\mathbf{C M T}=$ Charcot-Marie-Tooth disease; IgG = immunoglobulin G; IgG4 = immunoglobulin G4; IgM = immunoglobulin M; IHC = immunohistochemistry; NF140/186 = nodal neurofascin; NF155 = neurofascin-155; OD = optical density; PBS = phosphate-buffered saline; RT = room temperature.

Disease-specific and clinically relevant antibodies targeting proteins located at the node and paranode of Ranvier have been described recently in small subsets of patients with chronic inflammatory demyelinating polyradiculoneuropathy (CIDP). A small percentage (around 10\%) of patients with CIDP has antibodies against neurofascin-155 (NF155), nodal neurofascin (NF140/186), contactin-1, CASPR1, or the contactin-1/CASPR1 complex. ${ }^{1}$ Most patients with nodal or paranodal antibodies have antibodies of the immunoglobulin G4 (IgG4) isotype. ${ }^{2,3}$

The detection of these specific autoantibodies had been restricted to patients with inflammatory neuropathies. Last year, a report described immunoglobulin G (IgG) and immunoglobulin $\mathrm{M}(\mathrm{IgM})$ antibodies against neurofascin in patients with genetic and idiopathic neuropathies in addition to CIDP. ${ }^{4}$ The authors reported $14 \%$ positivity in patients with inflammatory neuropathies, $3 \%$ in patients with genetic neuropathies, and $7 \%$ in patients with idiopathic neuropathies, ${ }^{4}$ using a cell-based assay (CBA) without any confirmatory technique. These results raise the question whether these antibodies play a role in the pathogenesis of genetic and idiopathic neuropathies and question the specificity and relevance of the findings for patients with CIDP.

Although genetic and idiopathic neuropathies have been included as controls in several other studies, no other group has studied the presence of nodal and paranodal antibodies in patients with genetic neuropathies.

We studied the presence of nodal and paranodal antibodies ( $\operatorname{IgG}$ or $\operatorname{IgM}$ ) in patients with genetic neuropathies.

\section{Methods}

\section{Standard protocol approvals, registrations, and patient consents}

A total of 108 patients diagnosed with inherited neuropathies, followed up in our hospitals and from whom serum samples were available, were included in the study. Thirty-one were followed in Hospital de la Santa Creu i Sant Pau, 45 in Hospital Universitari Politènic de la Fe, and 32 in Hospital Universitario Marqués de Valdecilla. Patients were recruited during the 2017-2019 period.

Serum samples were aliquoted and stored at $-80^{\circ} \mathrm{C}$ until needed. All patients gave written informed consent to participate in the study. Written informed consents were obtained from all participants according to the Declaration of Helsinki. Participation in the study was conducted under a protocol approved by the Ethics Committee of the Hospital de la Santa Creu i Sant Pau. All experiments were performed in accordance with the relevant guidelines and regulations. Regarding experiments involving pigs, all experimental procedures were approved by our institution's Service of Animal Experimentation at CSIC-Institut Català de Ciències Cardiovasculars and were performed in accordance with guidelines and regulations.

\section{Immunocytochemistry}

Mammalian expression vectors encoding human NF155, NF140, NF186, CNTN1, CASPR1, and LRP4 were transfected in HEK293 cells with Lipofectamine 2000 (Invitrogen, Carlsbad, CA). Cells were then fixed with $4 \%$ paraformaldehyde (Affymetrix, Santa Clara, CA) and blocked. Immunocytochemistry experiments were performed using patients' sera and appropriate primary and secondary antibodies as previously described. ${ }^{5}$

\section{ELISA}

Maxisorb 96-well plates (Nunc; Thermo Fisher Scientific, Roskilde, Denmark) were coated with human NF155 or NF140 (recombinant protein of human neurofascin; Origene Technologies, Rockville, MD) diluted at a concentration of $1 \mu \mathrm{g} / \mathrm{mL}$ in $0.1 \mathrm{M}$ carbonate buffer ( $\mathrm{pH}$ 9.6) and incubated at $4^{\circ} \mathrm{C}$ overnight. All wells were washed with phosphate-buffered saline (PBS)/0.1\%Tween-20 and blocked with blocking solution (PBS, 5\% milk, 0.1\% Tween-20) for 1 hour at room temperature (RT). All wells were incubated with patient sera diluted 1:100 (1 hour at RT). We used sera from patients with positive IgG NF155 or NF140 as controls. After washing with PBS/0.1\% Tween-20, the plate was incubated with peroxidase-conjugated secondary antibodies (anti-human IgM [Dako, Glostrup, Denmark], diluted at 1:2,000, and anti-human IgG, Dako, 1:5,000). After washing with PBS/ $0.1 \%$ Tween-20, $100 \mu \mathrm{L}$ of TMB solution (BioLegend, San Diego, CA) was added to each well and the reaction was stopped after 10 minutes by addition of $50 \mu \mathrm{L}$ of $25 \%$ sulfuric acid. Optical density (OD) was measured at $450 \mathrm{~nm}$ with multiscan ELISA reader. Results were represented as the difference of the OD. Samples were considered positive by ELISA when they had a $\Delta$ OD higher than mean healthy control $\triangle$ OD plus 2 SDs. All samples were tested under the same conditions. All statistical analyses were performed with GraphPad Prism v8. 


\section{Teased-nerve fibers immunohistochemistry (IHC)}

Sciatic nerves were removed from Sus scrofa domestica and were prefixed in 2\% paraformaldehyde for 1 hour. The sciatic nerve was washed with PBS, 3 times for 15 minutes, in agitation and ice. Teased fibers were prepared by gently teasing the single nerve fibers with 2 fine forceps on a glass slide for 1 hour. Teased fiber preparations were air-dried and stored at $-20^{\circ} \mathrm{C}$ until needed. To perform the IHC, teased fiber preparations were fixed with acetone for 10 minutes at RT, washed 2 times with PBS for 5 minutes, and blocked with triton $0.1 \%$ diluted in goat serum 5\% for 1 hour at RT in a humid chamber. The preparations were incubated for 1 hour with patients' sera diluted 1 : 100 in blocking solution (triton $0.1 \%$ diluted in goat serum 5\%), following incubation for 1 hour with commercial primary antibody anti-neurofascin (AF3235; R\&D Systems, Minneapolis, MN) diluted 1/500 and incubation for 1 hour with secondary antibodies, goat anti-chicken IgY Alexa Fluor 488 (A11039; Thermo Fisher Scientific) and goat anti-human IgG 594 (109-585-003; Jackson ImmunoResearch, Cambridge, UK) diluted $1 / 1,000$. Between incubations, 2 washes of 5 minutes with PBS in agitation were performed. Slides were mounted with Fluoromount (Diagnostic BioSystems, Inc., Fremont, CA). Images were acquired using a fluorescence microscope (Olympus [Tokyo, Japan] DX51). Sera of patients with anticontactin-1 IgG-positive CIDP were used as a positive control.

\section{Data availability}

Anonymized data not published within the article are available on request.

Table Charcot-Marie-Tooth (CMT) subtypes and genetic mutations

\begin{tabular}{|c|c|c|c|}
\hline CMT subtype & Gene & EMG classification & No. of patients \\
\hline CMT1A & PMP22 duplication & Demyelinating & 40 \\
\hline СMT1B & $M P Z$ & Demyelinating & 5 \\
\hline CMT1C & LITAF & Demyelinating & 3 \\
\hline CMTX1 & GJB1 & Demyelinating and axonal & 9 \\
\hline СMT2 & $M M E$ & Axonal & 3 \\
\hline CMT2F & HSPB1/HSP27 & Axonal & 3 \\
\hline СMT2H/K & GDAP1 & Axonal & 3 \\
\hline CMT2A & MFN2 & Axonal & 1 \\
\hline CMT2C & TRPV4 & Axonal & 1 \\
\hline CMT2D & GARS & Axonal & 1 \\
\hline CMT2J & PO & Axonal & 1 \\
\hline CMT2P & LRSAM1 & Axonal & 3 \\
\hline CMT2T & $D N A J B 2$ & Axonal & 1 \\
\hline CMT4B2 & $S B F 2$ & Demyelinating & 1 \\
\hline CMT4C & SH3TC2 & Demyelinating & 4 \\
\hline CMT4D (Lom) & NDRG1 & Demyelinating & 1 \\
\hline CMT4G (HMSN-Russe) & HK1 & Demyelinating & 1 \\
\hline HNPP & PMP22 deletion & Demyelinating & 4 \\
\hline HSAN & - & Axonal & 2 \\
\hline HSN & SPTLC1 & Axonal & 1 \\
\hline FAP & $T T R$ & Axonal & 4 \\
\hline DSMA & UBA1, VCP, NEK1 & Axonal & 3 \\
\hline CANVAS & RFC1 & Sensory neuronopathy & 1 \\
\hline Not genetically confirmed & - & 7 Demyelinating, 5 axonal & 12 \\
\hline
\end{tabular}

Abbreviations: CANVAS = cerebellar ataxia with neuropathy and bilateral vestibular areflexia syndrome; DSMA = distal spinal muscular atrophy; FAP = familial amyloid polyneuropathy; HMSN = hereditary motor and sensory neuropathy; HNPP = hereditary neuropathy with pressure palsies; HSAN = hereditary sensory and autonomic neuropathy; HSN = hereditary sensory neuropathy. 


\section{Results}

A total of 108 patients with inherited neuropathies were included in the study. The Charcot-Marie-Tooth disease (CMT) subtypes are detailed in the table. Twelve patients had a CMT phenotype without genetically confirmed diagnosis, 4 patients had a hereditary neuropathy with pressure palsies, 4 patients had a familial amyloidotic polyneuropathy, 3 patients had a distal spinal atrophy, and 1 patient had a CMT with neuromyotonia due to a HINT mutation.

Immunocytochemistry experiments were performed in all patients, testing $\operatorname{IgG}$ and $\operatorname{IgM}$ antibodies against NF155, NF140, Nf186, and CNTN1. Six patients with CMT seemed to react against nodal neurofascin in IgM experiments but clear positive staining in the cell-based assays and colocalization with the commercial antibody were uncertain. These patients tested negative for the same antigen by ELISA. A similar staining pattern was detected in 2 patients with CMT for IgG against nodal neurofascin, but they also tested negative by ELISA or IHC. The results are summarized in figure 1 .

One patient with CMT with a confirmed GJB1 mutation had a staining pattern compatible with the presence of $\operatorname{IgG}$ antibodies against NF155. This sample was confirmed to be positive by ELISA (1/900), but did not show the typical paranodal pattern by IHC. This patient had a typical GJB1 phenotype with a confirmed mutation that segregates in the family. The patient showed a similar staining pattern in transfected HEK293 cells with LRP4, an antigen related to seronegative myasthenia gravis. ${ }^{6,7}$

Our LRP4 plasmid shares the same C-terminal tag as the NF155 plasmid, suggesting that the positive staining against NF155 in this patient was due to antibodies targeting the
DDK-Myc tag of the neurofascin-155 and LRP4 plasmids (figure 2). This also explains the positivity in immunocytochemistry and ELISA (recombinant NF155 is purified from NF155-DDK/Myc-transfected HEK293 cells) and the absence of paranodal staining in IHC.

\section{Discussion}

Our study failed to replicate the presence of $\operatorname{IgG}$ and $\operatorname{IgM}$ antibodies targeting nodo-paranodal proteins in genetic neuropathies. It also highlights the need to use confirmatory techniques that provide higher test reliability when these laboratory tests are used for clinical purposes in CIDP and other inflammatory neuropathies.

The discovery of IgG4 nodal and paranodal autoantibodies has changed the classification and treatment algorithms of inflammatory neuropathies. ${ }^{1,8}$ When we stratify patients with CIDP according to these autoantibodies, their apparent clinical and immunopathologic heterogeneity disappears. For example, IgG4 antibodies against NF155 have been associated with predominantly distal motor symptoms, ataxia and tremor with cerebellar features, ${ }^{2}$ the DRB1*15 HLA class II alleles, and highly specific pathologic features. ${ }^{9}$ Furthermore, their discovery has changed the treatment paradigms in these patients: patients with CIDP with NF155 or CNTN1 antibodies are frequently resistant to IV immunoglobulin treatment and potentially responsive to rituximab. ${ }^{10}$

Although neurofascin was initially described as a possible antigen for multiple sclerosis, ${ }^{11}$ no other subsequent studies have demonstrated the presence of neurofascin antibodies in this disease. ${ }^{12}$ Antibodies against neurofascin also have been described in other diseases, such as neuromyelitis optica ${ }^{13}$ or combined central and

Figure 1 Results of immunocytochemistry (ICC) in transfected HEK293 cells

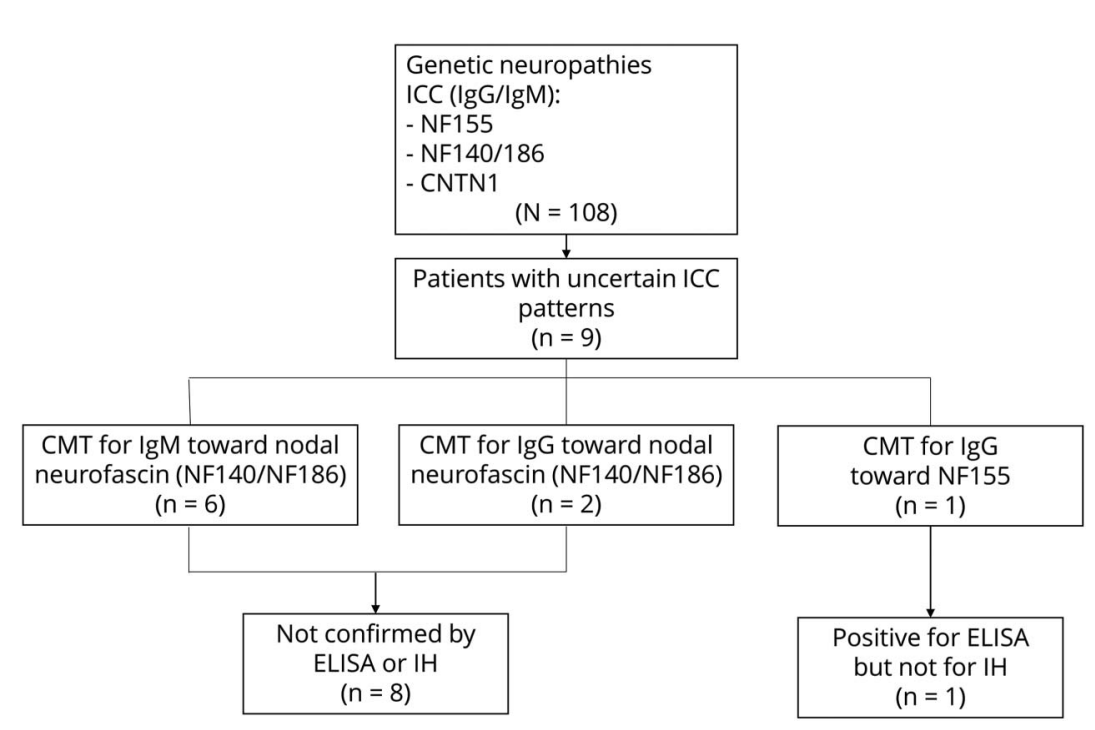

CMT = Charcot-Marie-Tooth; IgG = immunoglobulin G; IgM = immunoglobulin $\mathrm{M} ; \mathrm{IH}=$ immunohistochemistry; NF155= neurofascin-155; NF140/186 = nodal 
Figure 2 Results of immunocytochemistry and immunohistochemistry for the patient with GJB1 Charcot-Marie-Tooth (CMT)

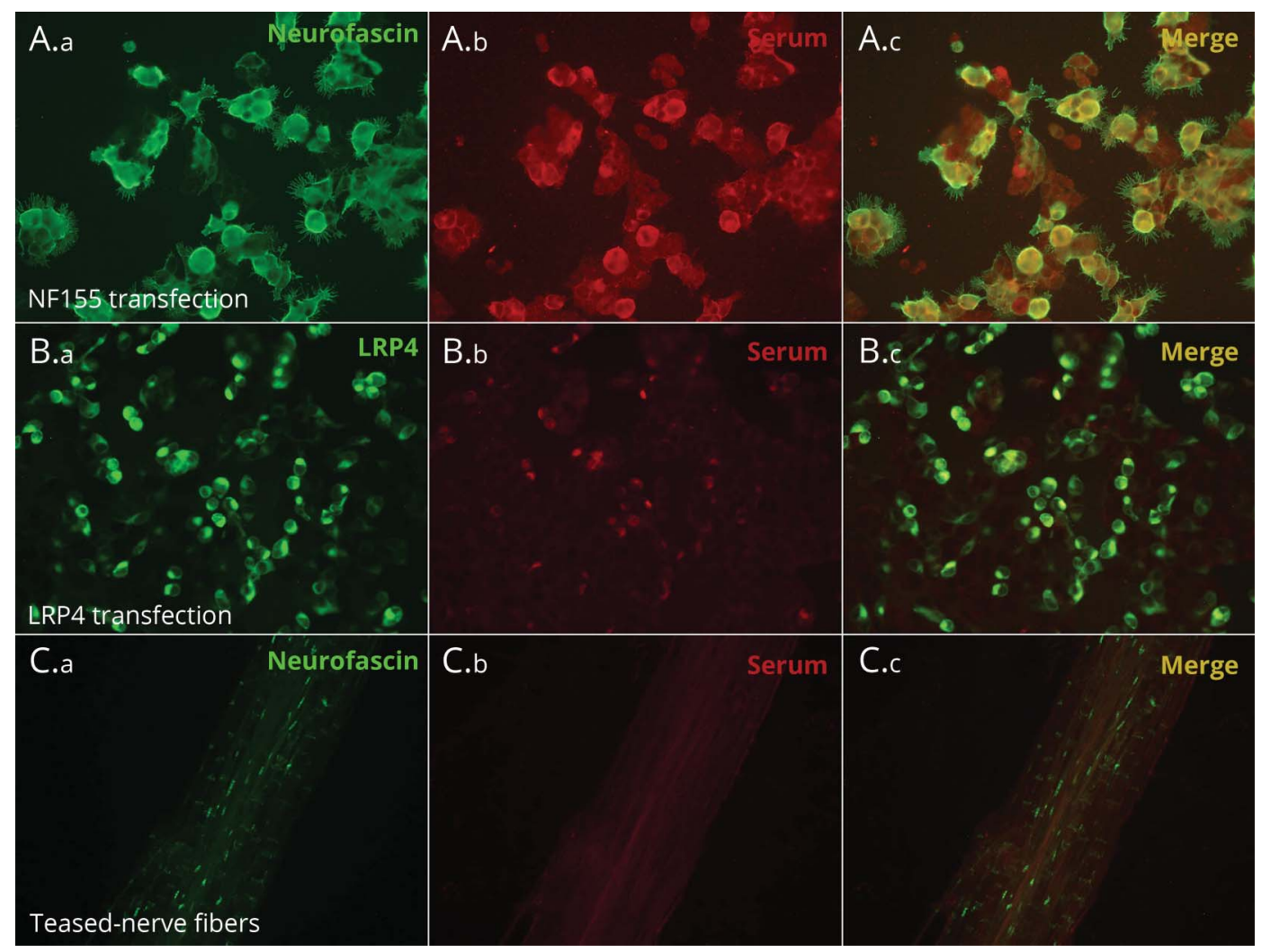

(A) immunocytochemistry in neurofascin-155-transfected HEK293 cells (40x original magnification). (B) Immunocytochemistry in LRP4-transfected HEK293 cells (20x original magnification). (C) Immunohistochemistry in pig teased-nerve fibers (20× original magnification). Column 1 (A.a., B.a., C.a.) is for commercial antibody, column 2 (A.b., B.b., C.b.) for secondary antibody, and column 3 (A.c., B.c., C.c.) for merged image between both. In this figure, we can observe a doubtful pattern without complete colocalization (A.c) between the commercial antibody (A.a) and the secondary antibody (A.b). A similar pattern can be observed in LPR4-transfected HEK293 cells (B.b), without a clear colocalization (B.c). The patient was clearly negative for immunohistochemistry (C.b).

peripheral demyelination, ${ }^{14}$ but these results have not been confirmed in other studies. ${ }^{15}$ Since the description of IgG4 antibodies in $\mathrm{CIDP},{ }^{1-3}$ antibodies against neurofascin and contactin- 1 have only been related to patients with inflammatory neuropathies and several hundred control samples tested negative in the reports describing their association with CIDP. A recent meta-analysis on paranodal antibodies describes a low sensitivity but a high specificity of nodo-paranodal autoantibodies to diagnose CIDP, supporting the importance of these autoantibodies to identify subsets of patients with homogeneous features. ${ }^{16}$ These antibodies are predominantly IgG4 subclass, ${ }^{2,3}$ which does not activate complement or cell-mediated cytotoxicity. ${ }^{17}$ Furthermore, pathogenicity of human-derived neurofascin-155 and contactin-1 antibodies in CIDP has been demonstrated recently in passive-transfer animal models. ${ }^{18,19}$

Burnor et al. ${ }^{4}$ described the presence of neurofascin antibodies in patients with genetic neuropathies (3\%) and idiopathic neuropathies (7\%). The antibodies found in genetic neuropathies were anti-NF155 IgM in 2 patients with CMT and anti-NF155 IgG in 1 patient with CMT, with a predominant IgG1 subclass. They also found antibodies of the IgM isotype against neurofascin in patients with Guillain-Barré syndrome and CIDP: 3 patients with anti-NF186 IgM and 3 patients with anti-NF155 IgM antibodies. Confirmatory techniques were not used. If replicated, these results would challenge the idea that nodo-paranodal autoantibodies associate with specific CIDP phenotypes and would support the idea that an antigen-specific immune response may play a role in some patients with genetic neuropathy. However, we have tested 108 patients with genetic neuropathies from 3 different centersmost of them patients with CMT — without finding any patient clearly positive for IgG or IgM against nodal neurofascin (NF140/NF186), paranodal neurofascin (NF155), or CNTN1. A small proportion of patients, comparable to that found by Burnor et al., ${ }^{4}$ showed an uncertain staining pattern in the CBA that was not detected when using confirmatory techniques.

There are several factors that may explain the differences in our 2 reports. First, Burnor et al. ${ }^{4}$ used pFLAG vector encoding mouse NF186 and pcDNA3 vector encoding rat NF155. The use of rat NF155 protein to detect anti-NF155 antibodies has proven unspecific in previous reports ${ }^{15}$ in comparison with human recombinant protein. Also, the pFLAG-NF186 plasmid used by Burnor et al. ${ }^{4}$ includes an intracytoplasmic tag that, although most of the times should 
not be critical, in our experience, as we demonstrate with the patient reacting against both the NF155-transfected and the LRP4-transfected cells, that share the same tag, results in falsepositives that are almost impossible to differentiate from truepositives unless a second confirmatory technique, in which the tag is not present, is performed. Second, when test results could eventually be used to change the therapeutic approach, we aim for high specificity in the detection of the autoantibodies even if this results in loss of sensitivity.

In the original reports and replication studies describing the presence of nodo-paranodal autoantibodies in CIDP immunocytochemistry, CBA is the gold standard technique for detection of these autoantibodies. False-positive results are rare in CBA but they do appear, especially when testing large cohorts. Considering the very low frequency at which these autoantibodies appear even in CIDP, the potential for false positivity needs to be minimized carefully. Careful visual assessment of true colocalization of the fluorescence of the secondary antibodies detecting human $\operatorname{IgG}$ and the commercial antibody against the antigen of interest is critical (and often difficult) and that is why, as a reference laboratory in the field, we recommend confirming positive results by another technique (usually ELISA with human recombinant protein) and, ultimately, by IHC, if the technique is available. True positive sera in the CBA invariably react against the antigen of interest in ELISA and teased-nerve fibers with the typical nodal or paranodal pattern and when this does not happen, positivity needs to be reassessed.

A limitation of our study, considering the very low frequency in which these antibodies appear in populations at risk (inflammatory neuropathies), is the sample size. We cannot exclude the possibility that some patients with genetic neuropathies have antibodies against nodo-paranodal proteins, but our study suggests that this possibility is unlikely.

We have not been able to detect IgG or IgM nodo-paranodal antibodies in our cohort of patients with hereditary neuropathies using diverse laboratory techniques. These findings reinforce the idea that the presence of nodal and paranodal antibodies is highly specific for specific CIDP subgroups and their detection should be systematized in patients with the typical phenotypes or who do not respond to conventional therapies. Autoantibody testing should always consider the use of confirmatory techniques, especially when the CBA results are uncertain or the clinical suspicion is low.

\section{Study funding}

This work is supported by Fondo de Investigaciones Sanitarias (FIS), Instituto de Salud Carlos III, Spain, and FEDER under grant FIS16/00627; and personal grant SLT006/17/ 00131 of the Pla estratègic de recerca i innovació en salut (PERIS), Departament de Salut, Generalitat de Catalunya.

\section{Disclosure}

L. Martín-Aguilar has received speaking honoraria from Roche. E. Pascual-Goñi has received speaking honoraria from Roche and Biogen. C. Lleixà, M. Frasquet, H. Argente, and A. CanoAbascal report no disclosures. J. Díaz-Manera has provided expert testimony for PTC and Sanofi-Genzyme; has been external advisor for Sanofi, Sarepta, and Audentes; and received research funds from Sanofi-Genzyme and Boehringer. E. Cortés-Vicente, A.L. Pelayo, T. Sevilla, and R. Rojas-García report no disclosures. L. Querol has provided expert testimony for Grifols, SanofiGenzyme, Novartis, UCB, Roche, and CSL Behring; and received research funds from Novartis Spain, Sanofi-Genzyme, and Grifols. Go to Neurology.org/N for full disclosures.

\section{Publication history}

Received by Neurology October 1, 2019. Accepted in final form January 5, 2020.

\begin{tabular}{|c|c|c|}
\hline Name & Location & Contribution \\
\hline $\begin{array}{l}\text { Lorena } \\
\text { Martín- } \\
\text { Aguilar, MD }\end{array}$ & $\begin{array}{l}\text { Hospital de la Santa Creu } \\
\text { i Sant Pau, Barcelona, } \\
\text { Spain }\end{array}$ & $\begin{array}{l}\text { Acquired data, performed } \\
\text { the experiments, analyzed } \\
\text { the data, drafted the } \\
\text { manuscript for intellectual } \\
\text { content }\end{array}$ \\
\hline
\end{tabular}

Elba Hospital de la Santa Creu Major role in the acquisition

Pascual- i Sant Pau, Barcelona, of data and performed the

Goñi, MD Spain $\quad$ experiments

\begin{tabular}{lll}
\hline $\begin{array}{l}\text { Cinta } \\
\text { Lleixà, MD }\end{array}$ & $\begin{array}{l}\text { Hospital de la Santa Creu } \\
\text { i Sant Pau, Barcelona, } \\
\text { Spain }\end{array}$ & $\begin{array}{l}\text { Major role in the acquisition } \\
\text { of data and performed the } \\
\text { experiments }\end{array}$ \\
\hline $\begin{array}{l}\text { Marina } \\
\text { Frasquet, } \\
\text { MD }\end{array}$ & $\begin{array}{l}\text { Hospital Universitari i } \\
\text { Politècnic de la Fe, } \\
\text { Valencia, Spain }\end{array}$ & Acquired samples and data \\
\hline
\end{tabular}

\begin{tabular}{lll}
\hline Herminia & Hospital Universitari i & Acquired samples and data \\
Argente, & Politècnic de la Fe, & \\
MD & Valencia, Spain &
\end{tabular}

MD Valencia, Spain

\begin{tabular}{|c|c|c|}
\hline $\begin{array}{l}\text { Angel Cano- } \\
\text { Abascal, } \\
\text { MD }\end{array}$ & $\begin{array}{l}\text { Hospital Universitario } \\
\text { Marqués de Valdecilla, } \\
\text { Santander, Spain }\end{array}$ & Acquired samples and data \\
\hline $\begin{array}{l}\text { Jordi Diaz- } \\
\text { Manera, } \\
\text { MD, PhD }\end{array}$ & $\begin{array}{l}\text { Hospital de la Santa Creu } \\
\text { i Sant Pau, Barcelona, } \\
\text { Spain }\end{array}$ & $\begin{array}{l}\text { Acquired samples and } \\
\text { data, revised the manuscript } \\
\text { for intellectual content }\end{array}$ \\
\hline $\begin{array}{l}\text { Elena } \\
\text { Cortés- } \\
\text { Vicente, } \\
\text { MD, PhD }\end{array}$ & $\begin{array}{l}\text { Hospital de la Santa Creu } \\
\text { i Sant Pau, Barcelona, } \\
\text { Spain }\end{array}$ & $\begin{array}{l}\text { Revised the manuscript for } \\
\text { intellectual content }\end{array}$ \\
\hline $\begin{array}{l}\text { Ana Lara } \\
\text { Pelayo, MD, } \\
\text { PhD }\end{array}$ & $\begin{array}{l}\text { Hospital Universitario } \\
\text { Marqués de Valdecilla, } \\
\text { Santander, Spain }\end{array}$ & $\begin{array}{l}\text { Acquired samples and data, } \\
\text { revised the manuscript for } \\
\text { intellectual content }\end{array}$ \\
\hline $\begin{array}{l}\text { Teresa } \\
\text { Sevilla, MD, } \\
\text { PhD }\end{array}$ & $\begin{array}{l}\text { Hospital Universitari i } \\
\text { Politècnic de la Fe, } \\
\text { Valencia, Spain }\end{array}$ & $\begin{array}{l}\text { Acquired samples and data, } \\
\text { revised the manuscript for } \\
\text { intellectual content }\end{array}$ \\
\hline $\begin{array}{l}\text { Ricard } \\
\text { Rojas- } \\
\text { García, MD, } \\
\text { PhD }\end{array}$ & $\begin{array}{l}\text { Hospital de la Santa Creu } \\
\text { i Sant Pau, Barcelona, } \\
\text { Spain }\end{array}$ & Acquired samples and data \\
\hline $\begin{array}{l}\text { Luis Querol, } \\
\text { MD, PhD }\end{array}$ & $\begin{array}{l}\text { Hospital de la Santa Creu } \\
\text { i Sant Pau, Barcelona, } \\
\text { Spain }\end{array}$ & $\begin{array}{l}\text { Designed and conceptualized } \\
\text { the study, interpreted } \\
\text { the data, revised the } \\
\text { manuscript for intellectual } \\
\text { content }\end{array}$ \\
\hline
\end{tabular}




\section{References}

1. Querol L, Devaux J, Rojas-Garcia R, Illa I. Autoantibodies in chronic inflammatory neuropathies: diagnostic and therapeutic implications. Nat Rev Neurol 2017;13:533-547.

2. Querol L, Nogales-Gadea G, Rojas-Garcia R, et al. Neurofascin IgG4 antibodies in CIDP associate with disabling tremor and poor response to IVIg. Neurology 2014;82:879-886.

3. Querol L, Nogales-Gadea G, Rojas-Garcia R, et al. Antibodies to contactin-1 in chronic inflammatory demyelinating polyneuropathy. Ann Neurol 2013;73:370-380.

4. Burnor E, Yang L, Zhou H, et al. Neurofascin antibodies in autoimmune, genetic, and idiopathic neuropathies. Neurology 2018;90:e31-e38.

5. Querol L, Siles AM, Alba-Rovira R, et al. Antibodies against peripheral nerve antigens in chronic inflammatory demyelinating polyradiculoneuropathy. Sci Rep 2017;7:14411.

6. Higuchi O, Hamuro J, Motomura M, Yamanashi Y. Autoantibodies to low-density lipoprotein receptor-related protein 4 in myasthenia gravis. Ann Neurol 2011;69: 418-422.

7. Zhang B, Tzartos JS, Belimezi M, et al. Autoantibodies to lipoprotein-related protein 4 in patients with double-seronegative myasthenia gravis. Arch Neurol 2012;69: 445-451.

8. Pascual-Goñi E, Martín-Aguilar L, Querol L. Autoantibodies in chronic inflammatory demyelinating polyradiculoneuropathy. Curr Opin Neurol 2019;32:651-657.

9. Martinez-Martinez L, Lleixà MC, Boera-Carnicero G, et al. Anti-NF155 chronic inflammatory demyelinating polyradiculoneuropathy strongly associates to HLADRB15. J Neuroinflammation 2017;14:1-6.
10. Querol L, Rojas-García R, Diaz-Manera J, et al. Rituximab in treatment-resistant CIDP with antibodies against paranodal proteins. Neurol Neuroimmunol Neuroinflamm 2015;2:e149.

11. Mathey EK, Derfuss $\mathrm{T}$, Storch $\mathrm{MK}$, et al. Neurofascin as a novel target for autoantibody-mediated axonal injury. J Exp Med 2007;204:2363-2372.

12. Meinl E. Untapped targets in multiple sclerosis. J Neurol Sci 2011;311:S12-S15.

13. Jia K, Zhang X, Zhang LJ, et al. Anti-neurofascin- 155 antibody-positive neuromyelitis optica spectrum disorders. J Neurol Sci 2019;398:16-18.

14. Kawamura N, Yamasaki R, Yonekawa T, et al. Anti-neurofascin antibody in patients with combined central and peripheral demyelination. Neurology 2013;81:714-722.

15. Cortese A, Devaux JJ, Zardini E, et al. Neurofascin-155 as a putative antigen in combined central and peripheral demyelination. Neurol Neuroimmunol Neuroinflamm 2016;3:e238.

16. $\mathrm{Hu} \mathrm{W}$, Xin $\mathrm{Y}, \mathrm{He} \mathrm{Z}$, Zhao Y. Association of neurofascin IgG4 and atypical chronic inflammatory demyelinating polyneuropathy: a systematic review and meta-analysis. Brain Behav 2018;8:e1115.

17. Aalberse RC, Stapel SO, Schuurman J, Rispens T. Immunoglobulin G4: an odd antibody. Clin Exp Allergy 2009;39:469-477.

18. Manso C, Querol L, Mekaouche M, Illa I, Devaux JJ. Contactin-1 IgG4 antibodies cause paranode dismantling and conduction defects. Brain 2016;139:1700-1712.

19. Manso $\mathrm{C}$, Querol $\mathrm{L}$, Lleixà $\mathrm{C}$, et al. Anti-neurofascin-155 IgG4 antibodies prevent paranodal complex formation in vivo. J Clin Invest 2019;129:2222-2236. 


\section{Neurology}

Antibodies against nodo-paranodal proteins are not present in genetic neuropathies Lorena Martín-Aguilar, Elba Pascual-Goñi, Cinta Lleixà, et al.

Neurology 2020;95;e427-e433 Published Online before print February 26, 2020

DOI 10.1212/WNL.0000000000009189

This information is current as of February 26, 2020

$\begin{array}{ll}\begin{array}{l}\text { Updated Information \& } \\ \text { Services }\end{array} & \begin{array}{l}\text { including high resolution figures, can be found at: } \\ \text { http://n.neurology.org/content/95/4/e427.full }\end{array} \\ \text { References } & \text { This article cites } 19 \text { articles, } 6 \text { of which you can access for free at: } \\ \text { http://n.neurology.org/content/95/4/e427.full\#ref-list-1 } & \text { This article has been cited by } 1 \text { HighWire-hosted articles: } \\ & \text { http://n.neurology.org/content/95/4/e427.full\#\#otherarticles } \\ \text { Citations } & \text { This article, along with others on similar topics, appears in the } \\ & \text { following collection(s): } \\ \text { All CBMRT/Null Hypothesis } \\ \text { http://n.neurology.org/cgi/collection/all_cbmrt_null_hypothesis } \\ \text { Chronic inflammatory demyelinating polyneuropathy } \\ \text { http://n.neurology.org/cgi/collection/chronic_inflammatory_demyelinat } \\ \text { ing_polyneuropathy } \\ \text { Information about reproducing this article in parts (figures,tables) or in } \\ \text { its entirety can be found online at: } \\ \text { http://www.neurology.org/about/about_the_journal\#permissions } \\ \text { Permissions \& Licensing } & \text { Information about ordering reprints can be found online: } \\ & \text { http://n.neurology.org/subscribers/advertise }\end{array}$

Neurology ${ }^{\circledR}$ is the official journal of the American Academy of Neurology. Published continuously since 1951, it is now a weekly with 48 issues per year. Copyright () 2020 American Academy of Neurology. All rights reserved. Print ISSN: 0028-3878. Online ISSN: 1526-632X.

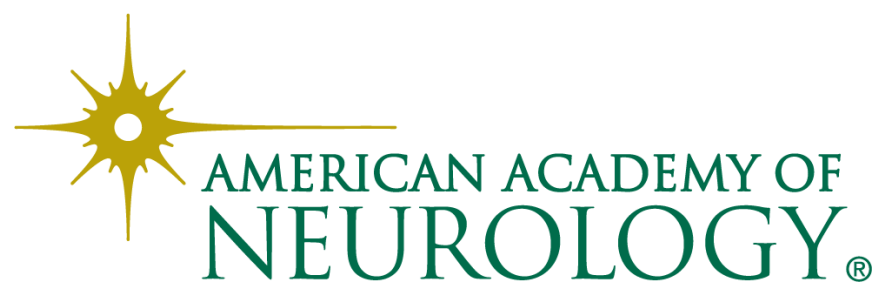

